\title{
The Impact of Knowledge Sharing and Innovation on Sustainable Performance in Islamic Banks: A Mediation Analysis through a SEM Approach
}

\author{
Jaffar Abbas ${ }^{1}{ }^{(\mathbb{D}}$, Iftikhar Hussain ${ }^{2}$, Safdar Hussain ${ }^{3,4}$, Sabahat Akram ${ }^{5}$, Imrab Shaheen ${ }^{6}$ \\ and Ben $\mathrm{Niu}^{3,7, *(\mathrm{D})}$ \\ 1 School of Media and Communication (SMC); Antai College of Economics and Management (ACEM) \\ Shanghai Jiao Tong University (SJTU), No. 800 Dongchuan Road Minhang District, Shanghai 200240, China; \\ abbas512@sjtu.edu.cn \\ 2 Dean: Faculty of Computing and Engineering, University of Kotli Azad Jammu and Kashmir (UOKAJK), \\ Kotli 111000, Pakistan \\ 3 College of Management, Shenzhen University, Shenzhen 518060, China \\ 4 Pir Mehr Ali Shah, Arid Agriculture University, Rawalpindi 46000, Pakistan \\ 5 Department of Economics, University of Kotli Azad Jammu and Kashmir (UOKAJK), \\ Kotli 111000, Pakistan \\ 6 Department of Public Administration, University of Kotli Azad Jammu and Kashmir (UOKAJK), \\ Kotli 111000, Pakistan \\ 7 Institute for Entrepreneurship (IfE), Great Bay Area International Institute for Innovation, \\ Shenzhen 518060, China \\ * Correspondence: drniuben@gmail.com
}

Received: 17 June 2019; Accepted: 25 July 2019; Published: 26 July 2019

check for updates

\begin{abstract}
This research is among the very few studies seeking a focalized examination on the relationship between knowledge sharing within a firm and organizational innovation. This specific study establishes that the knowledge sharing and innovation processes in Islamic banks are integral parts of the survival and progress of business organizations. Knowledge sharing and creativity are essential elements in the development of innovative strategies, but few studies have sought to investigate this relationship. This study proposes a framework with five hypotheses, which predicts the influences of knowledge sharing and organizational innovation on the Pakistani banking sector. This survey scrutinizes the impacts of knowledge sharing and innovation, and its primary objective is to determine how learning in Islamic banks mediates the relationship, and enhances the performance, of Pakistani Islamic banks. The authors distributed a self-administered survey, and randomly selected 554 employees from Mirpur AJ\&K, Rawalpindi and Islamabad, Pakistan. We screened and tested the data received using SPSS version 25 for analysis purposes to measure the strength of the relationships which exist among the studied variables. The findings indicate that all of the proposed hypotheses have significant positive relationships, proving that knowledge sharing and organizational innovation have mediating impacts upon organizational learning. The findings can also be used to propose a systematic and holistic framework for attaining an improved performance in Islamic banks through the mediating role of organizational learning. This study offers empirical evidence and original data to examine the connection between knowledge sharing, innovation processes and learning culture in Islamic Banks. The generalizability of these findings is restricted to Islamic banks, and the study delivers valuable insights and suggestions for imminent research studies.
\end{abstract}

Keywords: knowledge sharing; innovation; organizational learning; Islamic banking; Pakistan 


\section{Introduction}

Since the rise of the significant knowledge era, the values in organizations have been changing rapidly [1]. The continuing viability and success of firms are observed to be heavily reliant on the firms' capability to grasp the unseen value of their critically-attained, implicit as well as explicit knowledge [2]. In the recent past, the products and services of traditional labor and capital-centered firms have been increasingly substituted through the unceasing revolution by the needs, requirements and demands of customers with the introduction of knowledge-based businesses [3,4]. Knowledge sharing is categorically a vital factor for all firms, particularly for banking organizations. In today's competitive market, knowledge sharing plays a critically important role, as it improves not only the scholarly application, but also the creation of new knowledge that is owned by the personnel working in banks [5]. In an earlier study, Barachini (2009) stresses that firms need to inspire the workforce to share necessary information and critical knowledge regularly, and to grasp and reuse their knowledge assets [6]. Researchers and academics are focused upon the idea that organizations need to develop a culture of knowledge sharing and a supporting environment. Firms need to devise knowledge-friendly strategies to enable themselves to share, transmit and reuse valuable insights. Simultaneously, business firms all over the world are taking steps to introduce useful knowledge sharing methods and procedures into their daily work processes in order to improve creativity, innovation and organizational performance [7].

In the recent past, some Islamic commercial banks have introduced innovative products and Islamic services. Pakistani Islamic banks want to attract and maintain their customers instantaneously and at large, without sharing the basic knowledge about these products. This affects many business practices, particularly in the Pakistani banking sector. Thus, initiating and successfully implementing knowledge sharing practices in the banking sector is becoming crucial for banking sector growth in Pakistan [8]. Realizing the importance of knowledge management, especially knowledge sharing, the banking sector has initiated the development of knowledge management (KM) teams in their institutions [9]. Banks all over the world, including in Pakistan, especially the newly emerging Islamic banks, have realized that to contend with a recognized Pakistani, non-Islamic banking industry, and to ensure innovation in their Islamic products/services, a well-organized knowledge sharing system is required [10]. Knowledge sharing practices affect organizational innovation (OI). Useful knowledge sharing requires an improved organizational learning (OL) system for enhanced performance. Secondly, creativity and innovation largely depend upon the learning systems prevailing in these organizations. Therefore, the critical drivers for current research are to study the current knowledge sharing practices and strategies employed in Pakistani banks offering Islamic products. Their influences on these Islamic banks in terms of promoting enhancing innovation and creativity, by introducing Islamic products, enhance their overall performance. This research survey focuses on exploring the mediating impact of organizational learning through knowledge sharing and innovation processes by Islamic banks, and how this improves the sustainable performance of Pakistani Islamic banks.

In the past two decades, the literature indicates sustainable business growth in Pakistani Islamic banks, which is a positive sign in the business world. Business firms focus upon achieving sustainable growth, as it enhances economic growth in a competitive business environment. It also improves business firms' social performance, which refers to "Triple-P" (planet, people and profit). The role of innovation in bringing sustainable business growth has been the prime concern when suggesting that organizations commit to the bottom line of "Triple-P." However, the existing literature mostly examines the sustainable development and innovation associated with large-sized, multinational business firms, and the Islamic Banking industry is ignored, and therefore remains under-researched. This study also explores the roles of knowledge sharing and organizational learning $(\mathrm{OL})$ in the innovation and sustainable growth of the newly emerging Islamic banking sector in Pakistan by considering the core concept of innovation within the organizations. 


\subsection{Problem Statement}

The Islamic banking sector is increasing in size, and Pakistan is one country that has successfully managed to apply both conventional and Islamic banking practices and systems [10]. Islamic banks work independently, and attract consumers at large in Pakistan [11]. The problem this study is going to address concerns proper learning among the employees about Islamic banking practices, and then the sharing of this knowledge about Islamic banking practices to ensure innovation in products and services, which is needed to attract and retain customers in the banking sector [12]. This study focuses on the knowledge, abilities and skills of the personnel working in those Islamic Banks under investigation. Based on past literature, it is revealed that most of the workforce in Islamic banks lacks an understanding of Shari'ah rules, and this is due to the fact that the majority of the workforce has come from conventional banks [13]. Comparatively, traditional banks (non-Islamic) with their non-Islamic banking structure, offer the products and services of Islamic Banks, which causes uncertainty and dissatisfaction among customers who are seeking Islamic banking products and services [14]. The strategies and practices of Islamic banks are typically creating problems for the Islamic banking system, as well as for customers who are seeking to use the products and services of these Islamic banks. The products and services are based on Islamic principles, and these are entirely different from conventional banking products or services. The core products and services of Islamic banks are Wadiah (safekeeping), Mudharabah (profit sharing), Murabahah (cost plus), Musyarakah (joint venture), and Ijarah (leasing). Thus, the significant differences between Islamic and non-Islamic products and services characterizes and differentiates Islamic banking from the global banking system, which affects the equity-participation procedure. Islamic banking products offer predetermined returns/profits, which are not fixed, and are not guaranteed. Conventional banking is based upon both debt systems and equity, which are driven by fixed interest rates. These products and services have clear and fixed costs and profit systems. Secondly, there is also a problem with the specific implementation of Islamic banking principles [15]. The inefficient and ineffective knowledge sharing concerning the rules of Islamic banking, procedures and practices between the employees and the customers raise problematic concerns in Pakistan.

\subsection{Research Objectives and Questions}

This study aims to address the research gap identified and the problems discussed in this study through empirical research on organizational innovation. Organizational innovation is becoming a dire need of Islamic banks operating in Pakistan and other regions worldwide to solve the problems identified in this research. This study examines the association between knowledge sharing and innovation by Islamic banks with a mediating effect on Islamic banks' learning.

The objectives of this study are as follows:

1. To assess the relationship between knowledge sharing and innovation in Pakistani Islamic banks;

2. To assess the relationship between knowledge sharing and learning in Pakistani Islamic banks;

3. To assess the relationship between learning and organizational innovation in Pakistani Islamic banks;

4. To assess and test the mediating effect of learning on knowledge sharing and innovation in Pakistani Islamic banks.

This specific survey places an emphasis on accomplishing the research objectives mentioned above, and it sought to find the answers to the following questions:

Does a relationship between knowledge sharing and innovation exist in Pakistani Islamic banks? What is the association between knowledge sharing and learning in Pakistani Islamic banks? Is there any relationship between learning and organizational innovation in Pakistani Islamic banks? Does organizational learning mediate the relationship between knowledge sharing and organizational innovation in Pakistani Islamic banks? This specific research article comprises several sections. The first 
part of the paper presents the introduction, and the second section describes the literature review analysis, including an investigation of the study background and an outline of the hypotheses.

Chapter three focuses on the methods and materials. Chapter four describes the data, results, and the analysis concerning the objectives and research questions defined in the introduction section. Chapter five explains the essential discussions related to the acceptance of the proposed hypotheses based upon the study results. Section six displays the main conclusions and survey findings. The last section contains the recommendations and study implications.

\section{Critical Literature Review and Hypothesis Building}

\subsection{The Linkage of Knowledge Sharing and Innovation in Pakistani Islamic Banks (KS and OI)}

Knowledge is an excellent source of learning, and organizational learning is always competitive in the ever-changing market. Organizations require the creation and storage of knowledge, and the subsequent sharing of this knowledge with employees, individuals, teams and groups working with them. Knowledge sharing refers to the dissemination of organizational knowledge to all of the organization's stakeholders [16]. Knowledge sharing has a critical role in firms' business growth, since it supports businesses to generate new ideas, products, or services [17]. Knowledge sharing among employees ensures the transfer of thoughts, information, insights and experiences, and consequently, becomes a source of creativity and innovation in organizations [18]. The sharing of knowledge promotes the transmission of learning between teams, groups and individuals working within the organizations $[19,20]$. The purpose of knowledge sharing is to make the experience available to all the employees of the organization, whenever and wherever it is required to ensure the meaningful participation of employees [21], which makes the organization competitive [22,23]. In the past few decades, the literature provides evidence that the Islamic bank industry is growing, both in Islamic and non-Islamic sectors [24]. The growth of the Pakistani Islamic bank industry has been impressive over the last two decades $[10,15]$. Islamic banks follow Islamic principles, procedures, and rules (Sharia' $\mathrm{h}$ ) in their transactions $[25,26]$. Past literature endorses the fact that knowledge sharing strategies significantly influence a firm's success through their innovative performance processes. Darroch and McNaughton (2003) identify the fact that companies which employ better knowledge sharing practices remain more creative, and have better economic presentation [27]. They use the example that getting and sharing knowledge about the market in which a bank is serving is vital for encouraging innovation in banks' products and services that best fit customer needs [28]. In another study, López-Nicolás and Meroño-Cerdán (2011) measure the association of knowledge sharing strategies with creativity and innovation processes in Spanish firms, and they conclude that knowledge sharing policies stimulate firms' productivity by expanding their set of innovative skills and capabilities, helping to achieve sustainable performance [29]. Based on the above-mentioned existing literature on KS and OI, this proposed study tests the following hypothesis to assess the relationship between knowledge sharing and organizational innovation in Pakistani Islamic banks, and its effect on achieving sustainable performance in the Pakistani banking sector.

H1. A significant positive association exists between knowledge sharing and organizational innovation in Pakistani Islamic banks and the attainment of sustainable performance.

\subsection{Linkage of Islamic Banks Knowledge Sharing and Organizational Learning (KS and OL)}

Generally, knowledge sharing and learning are an integral part of attaining sustainable performance in Pakistani banks or organizations; however, knowledge sharing and organizational learning have a close relationship in Pakistani Islamic banks. Organizational Learning in Islamic banks consists of the process that leads to knowledge management, which offers organizational innovation in further stages. Knowledge management positively impacts organizational learning through a positive impact on innovative behaviors and a change in organizations [30,31]. Knowledge management provides a 
procedure which develops, stores, captures, shares, absorbs and utilizes organizational knowledge. These constituents of knowledge management are critical to improving organizational performance. Knowledge sharing is an integral part of an organization's process of knowledge management.

Moreover, knowledge sharing is an important factor in an organization's success and survival [32]. The knowledge absorbtion process is also a vital phase of knowledge management (KM). It facilitates knowledge sharing in businesses, and it improves organizational innovation performance [33]. There are many concerns in managing and sharing knowledge in organizations; for example, it is an expensive task, and both people and technology are involved in managing and sharing knowledge. There are also many political issues involved. Knowledge sharing is usually unnatural, as people are not inclined to share their experience if it is valuable [34]. In knowledge management, knowledge sharing seems to be the critical factor $[35,36]$. There are various kinds of knowledge management categorized in different ways; however, "tacit" and "explicit" knowledge are the typical basic categories of knowledge. The literature on knowledge management identifies different topologies for knowledge, with "explicit" and "tacit" being noteworthy knowledge types [37]. Explicit knowledge comes in written, codified, articulated or verbalized form. It is easily transferred and transmitted to others. Tacit knowledge is not in scriptural or coded form. The people themselves hold this kind of knowledge, which they might have learnt through experiences and situations. As this knowledge type is not in written form, it is challenging to transmit and share it with others $[38,39]$. Knowledge also exists at individual and social levels. Personal knowledge is the knowledge held by individuals, and social knowledge is owned by the whole community or by a group of people [40,41]. Spender (1996a; 1996b) combines personal and social knowledge with explicit and tacit knowledge to distinguish four types of knowledge [42,43]. Conscious knowledge is based on facts and figures, models and frameworks which an individual has and can retrieve from their memory [44]. Automatic knowledge includes the behavioral values, moral and social values, perceptions and beliefs of an individual, as well as a group or community, which, over a period of time, are adopted or gained by individuals or community groups [45]. Objectified knowledge is shared and codified knowledge that is explicitly used for professional uses within organizations [46,47]. Collective knowledge is a kind of knowledge that is rooted in the forms of communal and organizational practices, and resides further in the tacit experiences of the workforce [40,48]. Previous studies document that the concept of knowing comprises of thinking, acquiring, understanding, learning and sharing elements, which have a tradeoff connection [30,31]. In an earlier study, Yang (2007) recognize that knowledge sharing empowers firms to retain the individual learning flow throughout the firm, and it assimilates for day-to-day use, and he also argues that employees develop a common understanding through sharing their knowledge, thoughts, beliefs, experiences and insights; for example, common perceptions and the utilization of daily applications refer to organizational knowledge. Such sharing practices not only enhance workers' competencies through learning, but also contribute to overall organizational success [49]. This research study takes organizational learning capacity as a concept, and uses a definition given by the study of DiBella (1996). Within an organization, OL refers to the process or firms' capacity to maintain or improve their experience-based performance [50]. Organizational learning involves the acquisition of knowledge (developing skills and beneficial relationships), knowledge sharing (dissemination to other individuals of what someone has acquired), and finally, knowledge utilization (learning integration, which is assimilated, widely available, and might also be generalizable to new circumstances). Frequently, learning capability is necessary for the sustainable growth and development of businesses in the banking industry, which can grasp and use the acquired knowledge in daily banking operations to enhance organizational innovation through knowledge acquisition. The capability to learn frequently is necessary for sustainable growth and the development of businesses as it allows businesses to grasp and use the acquired knowledge in daily operations to enhance organizational innovation through knowledge [51-53]. The method of successful organizational learning through knowledge and information sharing among employees empowers firms and their employees to imitate their critical actions and behaviors, in order to gain understanding from an organizational setting at the 
workplace, allowing them to recognize situations and later to understand the conditions and respond in an appropriate way [6,54].

The existing literature suggests that knowledge sharing permits the banking sector to enhance organizational learning to achieve sustainable growth. The study proposes a correlational and explanatory (or causal) hypothesis based upon the literature mentioned above.

H2. Knowledge sharing positively influences organizational learning in Pakistani Islamic banks.

\subsection{Linkage of Islamic Banks/Organizational Learning and Innovation (OL and OI)}

The organization can progress at large when it enhances the learning system and process by introducing innovative products and services. Therefore, it will rationally affect improvement in its products and services, as the learning process of the business firms are rare, causing them to lose openings developed through the emerging needs of the customers. In a previous study, Aragón Correa et al. (2007) identifies a significant relationship between organizational learning and organizational innovation [55]. Further, they claim that, theoretically, organizational learning impacts corporate innovation, allowing the achievement of sustainable performance [56]. Considering various dimensions of organizational learning, past literature provides evidence that organizations practice a higher level of innovation in their processes following competitive learning processes, allowing them to achieve sustainable performance [57]. Santos et al. (2009), had a similar finding in their study: That organizations introduce innovative products and services through a very competitive business environment [58]. Several scholars argud and identify the idea that organizational learning narrates the prerequisites of corporate innovation, and it positively influences the innovation process $[59,60]$. These scholars realize that organizational learning enhances the rate of creativity/innovativeness in products and services, and previous literature indicates that an association between an increased percentage of organizational learning and the expansion of creativity in the firms exists [60-62]. The development of learning emphasizes the requirement for continuous evaluation and adaptation, and it refers to the rational debate that an organization's principles reinforce the willingness to adopt innovation and the inclination of different thoughts $[63,64]$. Accordingly, this study proposes the following hypothesis:

H3. Organizational learning positively influences organizational innovation in Pakistani Islamic banks.

\subsection{The Relationship among Learning, Knowledge Sharing, and Innovation (OL, KS, and OI) in Islamic Banks}

Organizational learning provides a platform for the development, retention and dissemination of knowledge within business organizations, thus ensuring that a reasonable level of organizational learning is significant for knowledge sharing [65]. Organizations' employees/workforce might change their job attitudes through knowledge sharing, which will subsequently affect their job behavior by stimulating the innovation process and achieving sustainable performance. Therefore, organizational learning might lead to the development of required information within business firms, which might create and extend an organization's internal knowledge sharing process, boosting the innovation process of the organization. Researchers achieve credible findings and initiate an investigation of knowledge sharing management, and scholars are increasingly examining the mechanism of knowledge sharing through OL. Experts have debated the influences of knowledge sharing business firms, and learning stages and workers have shared their motivational levels and frequently linked them with their capabilities [66]. The existing body of literature documents that qualifications, work experience, working relationships and individual income might meaningfully impact the particular KS, motivation and willingness [67]. A previous study reveals that organizations with employees who possess less job experience typically have higher intentions of carrying out KS, and scholars identify the same findings $[68,69]$. The outcomes of that study indicate that new employees tend to develop relations with colleagues, creating a channel for KS. Regarding the elements of knowledge sharing motivations, researchers conclude that "a greater professional level" is the primary motivator of sharing 
for individuals who make a higher income, while employees who are not part of management are usually interested in sharing to develop "coworkers' relationships."

Bilgihan et al. (2016) identify the idea that trust among employees encourages knowledge sharing behaviors in organizations. Trust typically plays a more significant role in employees being willing to share and metaphorically use knowledge. The willingness or desire of an employee to share or use knowledge depends on the knowledge levels of their co-workers who are trusted recipients of knowledge. The interpersonal trust between, and reputation of, coworkers, significantly affects employees' personal experiences within the business organization in terms of sharing, absorbing and transferring knowledge [70,71]. However, belief is also a necessary element that stimulates knowledge sharing among individuals [72]. Hence, knowledge sharing encourages the use and exchange of knowledge within an organization, which provides opportunities for employees to gain the latest experience that helps them to produce innovative performances. In turn, firms can achieve sustainable profit in a competitive business environment. Likewise, efficiency in an organizational innovation helps business firms to introduce new products or services, and it helps to modernize the obsolete structural and operational processes, which additionally might result in improvements to products and services to satisfy buyers and other stakeholders. Thus, the existing body of literature helps to categorize it in two phases. The first stage focuses on emphasizing the processes and mechanisms by which knowledge sharing contributes to organizational innovation performance, and the second phase identifies the factors which can mediate this mechanism. Based on the above-cited existing literature, this survey review identifies that organizational learning mediates the relationship between knowledge sharing and innovation in Pakistani Islamic banks. Based on the study review, the following hypothesis is proposed to examine this association between knowledge sharing and innovation in Islamic banks through the mediation of organizational learning:

H4. Organizational learning mediates a relationship between knowledge sharing and organizational innovation in Islamic banks.

\subsection{Research Framework}

Based upon the hypotheses of the current study and the literature cited in thesubsequent research framework, this study proposes the below model, which significantly affects employees' experiences in sharing, absorbing and transferring knowledge within an organization. Figure 1 shows the impact of knowledge sharing on organizational innovation through a mediating effect of organizational learning.

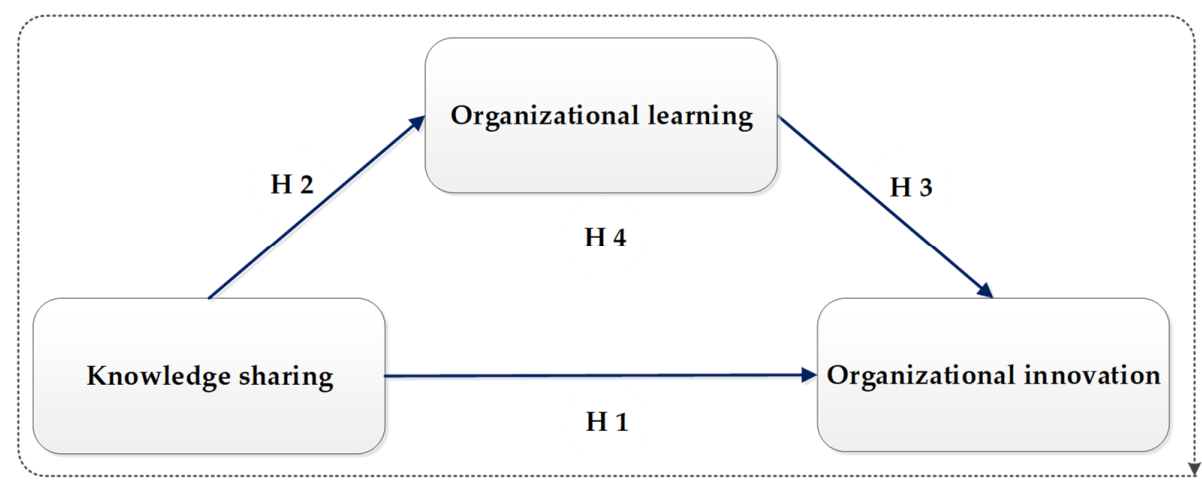

Figure 1. Research Framework: it shows the impact of KS on OI through a mediating effect of OL.

\section{Methods and Materials}

\subsection{Research Instruments}

This study proposes a model consisting of three factors to present the study framework. In this model, knowledge sharing (KS) in Islamic banks is the independent factor, organizational innovation 
(OI) is the dependent factor, and learning by Islamic banks is the mediating variable. This study selects survey items from previous studies with suitable adjustments in some mandatory sections.

\subsection{Designing a Questionnaire}

This study develops and distributes revised items of the selected variables through a self-structured survey that was completed by selected respondents of the targeted population to collect the desired data through a random sampling technique. This study invited participants, such as Branch Heads, Assistant Vice Presidents (AVPs), Managers of Operations, Marketing Managers, Relationship Managers, Managers of Sales and Credit Officers, from various banks. Participants were well-informed and trained on the study purpose, and we assured participants that all data received were kept strictly confidential. The survey also obtained information about the respondents' general profiles; for instance, age, education level, gender, profession and residential area. The study invited respondents from the Mirpur division, Rawalpindi and Islamabad, Pakistan. The questionnaire utilized a five-point Likert scale, which required individuals to rate their agreement from 1 (strongly disagree) to 5 (strongly agree).

\subsection{Sample Size-Target Population}

The population sample size contains the correct responses and focuses strictly on respondents from the Mirpur division, Rawalpindi and Islamabad, Pakistan. The respondents were required to be educated to at least a degree level. This study invited participants from six Pakistani Islamic banks, namely the Meezan Bank, Albaraka Bank, Dubai Islamic Bank, First Dawood Islamic Bank, Bank Islami Pakistan and the Emirates Global Islamic Bank, and respondents were selected from a list of the top Islamic banks in Pakistan published by the State Bank of Pakistan (SBP) in a report in 2018. We contacted the officials of the selected banks through personal visits and phone calls to clarify the purpose of this study, as well as to request that their officers/employees would contribute actively to this survey. The researchers omitted some respondents, as they were hesitant to answer questions during the pilot test, and they were not willing to participate in the study. We educated and trained the respondents about the survey's purpose, and the researchers gave the respondents 14 days to understand and to fill out the survey. The banks permitted their employees to participate in the survey, and we selected the scales from the literature to make an initial set of constructs. This study used a pilot study to check the effectiveness of the review well before starting the initial review. The participants of the pilot study were academicians, managers and officials with profound information and awareness of knowledge sharing, OI, and OL. Overall, we distributed 554 questionnaires among the employees of the six selected Islamic banks, and received back 287 complete and valid questionnaires $(51.80 \%)$. The authors received 267 (48.20\%) incomplete forms, which was a similar response rate to previous studies measuring knowledge sharing in a similar population [73]. We employed the technique of Armstrong and Overton (1977) to measure the possible non-response bias. We applied the Chi-square test and t-test to link the initial one hundred responses and the final one hundred responses based on the demographics, which comprised education level, age and gender. There was no observation of the substantial difference between the two selected sets of respondents at p-values higher than 0.05 , which suggested that no common method bias existed.

\subsection{Data Processing of the Questionnaires}

The researchers distributed 554 surveys among the employees and managers of six Pakistani Islamic banks operating businesses throughout Pakistan, and received back complete and valid forms of inquiries $(51.80 \%)$. We received 287 adequately-filled-out forms of the survey, and scrutinized them to confirm the accuracy of the data. This study processed the collected data and analyzed it by applying the analytical tool, a software package called the Statistical Package for the Social Sciences (SPSS-V-23). In the final step, the statistical analysis interpreted the results to provide useful insight and valuable evidence for the evaluation of the underlying factors. Figure 2 presents the three phases of the data collection procedure and see questionnaire items (Appendix A) which presents all the constructs. In the 
first phase, the authors selected the knowledge sharing of Islamic banks as an independent variable that influences the sustainable performance of Islamic banks. Organizational learning mediates a relationship between knowledge sharing and innovation (OI) in Islamic banks.

In phase two, through a pilot study, we gained a clear understanding of the reliability of the questionnaire items and modified it accordingly. In the third and final phase, we conducted the survey and received data from the respondents. Figure 2 presents data collection proce.

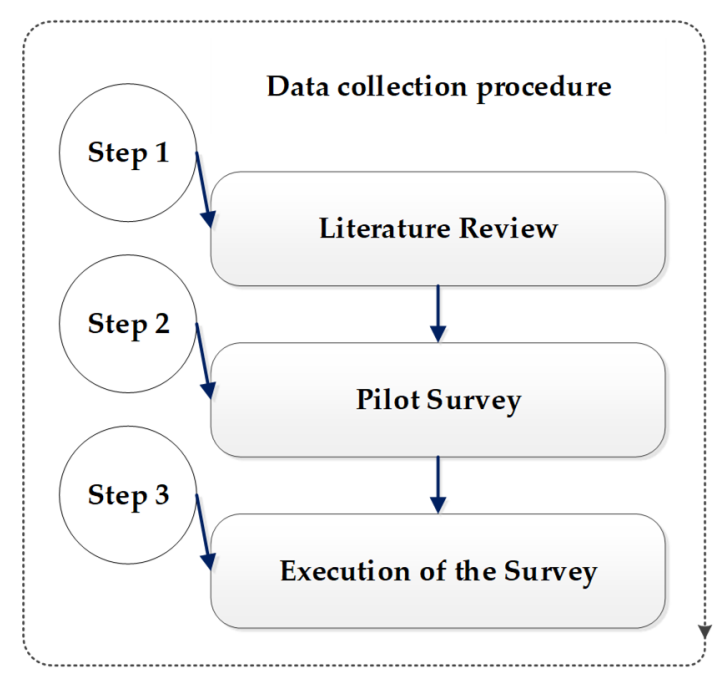

Figure 2. The procedure of data collection [74].

Table 1 demonstrates the results of the detailed characteristics of this study sample. From a sample of 287 participants, $232(80.80 \%)$ were male, and $55(19.20 \%)$ were female employees of the six Islamic banks operating in Pakistan. The items used were relevant to the factors explored, such as KS, organizational learning and organizational innovation in the respective banks.

Table 1. Demographic Characteristics.

\begin{tabular}{ccc}
\hline Characteristics & Frequency (f) & Percentage (\%) \\
\hline Male & Gender & \\
Female & 232 & 80.8 \\
& 55 & 19.2 \\
$1-5$ years & Experience & 33.1 \\
$6-10$ & 95 & 27.1 \\
$11-15$ & 78 & 22.0 \\
$>15$ & 63 & 17.8 \\
& 51 & 24.0 \\
$21-30$ years & Age & 42.9 \\
$31-40$ & 69 & 19.9 \\
$41-50$ & 123 & 13.2 \\
$>50$ & 57 & \\
& 38 & 8.0 \\
Intermediate & Education & 41.5 \\
Graduation & 23 & 50.5 \\
Masters & 119 & $\mathbf{1 0 0}$ \\
Total & 145 &
\end{tabular}

\subsection{Variable Measurement}

This study evaluates and measures the reliability and the validity of the selected instruments applied by scholars in the earlier research studies by taking the dimensions of the scales. The study 
also incorporates constructs by selecting relevant items by using a five-point Likert-scale to evaluate the scale items from 1 (strongly disagree) to 5 (strongly agree).

\subsubsection{Knowledge Sharing of Pakistani Islamic Banks}

This study reviews and evaluates knowledge sharing in Islamic banks by using five constructs adopted from a previous research study by Bock and Kim (2002), as explained in Table 2. These five constructs were knowledge sharing attributes including attitudes, behaviors and willingness of participants to share their knowledge and information, as well as the expectations of the procedure of knowledge sharing in terms of rewards and deep associations with their peers and colleagues [75].

Table 2. Constructs of knowledge sharing (KS).

\begin{tabular}{ccc}
\hline Construct & Definition & References \\
\hline Expected rewards & $\begin{array}{c}\text { One's belief that he/she will have rewards after } \\
\text { sharing his/her knowledge with others. } \\
\text { One's belief that after sharing knowledge, his/her ties } \\
\text { with other employees will strengthen. }\end{array}$ & {$[76-79]$} \\
Expected associations & $\begin{array}{c}\text { One's belief that after sharing his/her knowledge, the } \\
\text { overall performance of the firm will increase. } \\
\text { Level of someone's pleasant emotions after sharing } \\
\text { his/her knowledge }\end{array}$ & {$[85-88]$} \\
Attitude toward KS & Level of knowledge shared by someone. & {$[89-92]$} \\
Knowledge sharing behavior & [93-96] \\
\hline
\end{tabular}

\subsubsection{Organizational Innovation}

The literature contains a variety of measures used to determine innovation from a productivity point of view (e.g., innovative processes and products), inputs (research and development spending), or timings (innovators, early adopters, late adopters, and laggards). Consistent with Manu (1992), the current research employs three kinds of innovation as measures-administrative, product and processes-to describe the level of innovation, the resources banks spend on such changes and whether the innovation is reactive or proactive [97]. See Table 3 below;

Table 3. Constructs of organizational innovation (OI).

\begin{tabular}{cccc}
\hline Construct & Definition of the Construct & References \\
\hline Product innovation & $\begin{array}{c}\text { Product innovation is the outcome of processes involving time, individuals, } \\
\text { teams and training to develop and offer new products or services. It refers to a } \\
\text { tendency to introduce new products or services. }\end{array}$ \\
\hline Process innovation & $\begin{array}{c}\text { The innovation process requires numerous changes. It also refers to the tendency } \\
\text { to introduce new products or services. The innovation process demands a quick } \\
\text { reaction to new procedures introduced by competitors in the market. }\end{array}$ \\
\hline $\begin{array}{c}\text { Administrative } \\
\text { Innovation }\end{array}$ & $\begin{array}{c}\text { Administrative innovation refers to the novelty within the systems of the } \\
\text { [rganizations. Managers look for new and useful administrative systems. It also } \\
\text { relates to a tendency to introduce new administrative systems. }\end{array}$ \\
\hline
\end{tabular}

\subsubsection{Organizational Learning}

This study emphasizes the utilization of the model of organizational learning introduced by Huber. This study analyzes the literature and examines the previous studies conducted by Lei et al. (1999) and Slater and Narver (1993), as well as empirical studies executed by Hurley and Hult, (1998), Baker and Sinkula (1999), Jerez-Gomez et al. (2005), and Tippins and Sohi (2003), on the concept of organizational learning $[59,103-107]$. This study adopts the items on organizational learning from the previous work of Perez Lopez et al. (2004) [108]. Table 4 demonstrates the selected constructs of instruments, which contain four dimensions of the corporate learning process: Knowledge acquirement, distribution, interpretation and corporate memory.

This present study assesses organizational learning as a single concept through a proposed model containing its four sub-dimensions. See Table 4 below; 
Table 4. Constructs of organizational learning (OL).

\begin{tabular}{|c|c|c|}
\hline Construct & Definition & References \\
\hline Acquiring Knowledge & $\begin{array}{l}\text { The personnel often participate in shows and events to } \\
\text { gain knowledge. } \\
\text { Our firm has an original and consolidated research and } \\
\text { development policy. The firm regarly tests creative thoughts and } \\
\text { tactics in the workplace. }\end{array}$ & {$[105,106,108]$} \\
\hline Distributing Knowledge & $\begin{array}{l}\text { This firm takes proper actions to ensure the distribution of the best } \\
\text { practices between diverse activities. Some people in the firm } \\
\text { participate in different divisions or teams, and they perform as } \\
\text { connections among them. Some personnel have the responsibility } \\
\text { of gathering, accumulating, and disseminating workers' } \\
\text { recommendations. }\end{array}$ & {$[104-106,108]$} \\
\hline Interpreting Knowledge & $\begin{array}{l}\text { All employees of our firm convey a similar goal to which they are } \\
\text { dedicated. Workers exchange experiences and knowledge } \\
\text { through mutual conversions. Our firm usually practices and } \\
\text { encourages teamwork. }\end{array}$ & {$[103,106,108]$} \\
\hline Organizational Memory & $\begin{array}{l}\text { This firm has a complete record of employees/experts concerning } \\
\text { their area of specialization. If anyone needs to, he/she can find it at } \\
\text { any time. Our firm has a complete database of its customers. All } \\
\text { employees have access to the business firm's databases and } \\
\text { records. The firm updates the databases regularly. }\end{array}$ & {$[103,104,106-108]$} \\
\hline
\end{tabular}

\subsubsection{Control Variables}

Regarding the demographics of the sample in this study, control variables such as gender and education were selected to explore the possible variations between Islamic banks and their potential impacts on organizational innovation development. Wang and Hou (2015) also selected gender and education as control variables in their study [73].

\subsection{Methods Used for Analyzing Data}

This study applied AMOS, a method of the analysis of moment structures, to measure validity, and in the next stage, the study examined the SEM structural model by performing a structural equation modeling to test the model's hypotheses, which consisted of the responses of respondents working in the top six Islamic banks of Pakistan. The authors collected the survey forms from the respondents, screened them, and included only the properly filled out forms. This study applied SPSS and AMOS software version 24 for proper analysis, and the results revealed decent validity and a satisfactory level for the confirmatory factor analysis (CFA).

\section{Results and Analysis}

\subsection{Evaluating the Measurement Model}

We calculated the Cronbach's alpha values of all of the items on the scales to examine the reliability, which was 0.82 to 0.93 . All of the Cronbach's alpha values were higher than 0.70 , which was appropriate according to the standard [109] described by Nunnally and Bernstein (1994). The study applied CFA to measure the discriminant and convergent validity of the proposed research model. The factor loading values were 0.67 to 0.99 , which is beyond the standard range of 0.60 , at $\mathrm{p}<0.001$, and the sum of the composite reliability (CR) presents values within the limits of 0.82 to 0.92 , which is also above the threshold level of 0.70 . The results show AVE (the sum of the average variance extracted) values from 0.55 to 0.79 , which is was more than the cut-off point of 0.50 .

The study applies various methods and tools to assess and evaluate the convergent validity, and the results indicate that all of the constructs of this proposed study present a satisfactory level for the research instrument. Hair et al. [110] suggests a threshold level of 0.5 , and this proposed model also measures reliability, discriminant validity and the concurrent validity of all items before examining the 
hypotheses of this designed model. Table 5 provides the standard deviation (SD), mean (M), AVE, factor loading, $C \alpha$ and $C R$ values of all items and constructs.

Table 5. Reliability and Validity.

\begin{tabular}{|c|c|c|c|c|c|c|c|}
\hline Construct & Mean & SD & Item & Loading & AVE & CR & $\mathrm{C} \alpha$ \\
\hline \multirow[t]{5}{*}{ KS } & 3.58 & 0.52 & KS-1 & $0.73^{* * *}$ & 0.71 & 0.92 & 0.93 \\
\hline & & & KS-2 & $0.95^{* * *}$ & & & \\
\hline & & & KS-3 & $0.68^{* * *}$ & & & \\
\hline & & & KS-4 & $0.99^{* * *}$ & & & \\
\hline & & & KS-5 & $0.78^{* * *}$ & & & \\
\hline \multirow[t]{3}{*}{ OI } & 3.72 & 0.60 & OI-1 & $0.88^{* * *}$ & 0.79 & 0.92 & 0.92 \\
\hline & & & OI-2 & $0.85^{* * *}$ & & & \\
\hline & & & OI-3 & $0.92^{* *}$ & & & \\
\hline \multirow[t]{4}{*}{ OL } & 3.52 & 0.50 & OL-1 & $0.76^{* * *}$ & 0.55 & 0.82 & 0.82 \\
\hline & & & OL-2 & $0.77^{* * *}$ & & & \\
\hline & & & OL-3 & $0.67^{* * *}$ & & & \\
\hline & & & OL-4 & $0.75^{* * *}$ & & & \\
\hline
\end{tabular}

This study measure the average variance extracted (AVE) values by adopting Fornell and Larcker's (2018) measures of AVE for the assessment of discriminant validity (CV) [111]. Table 6 demonstrates the square root values of the AVE for the entire constructs (see the diagonal elements in italics). They indicate satisfactory relationships among the constructs of this proposed model and prove that the discriminant validity (DV) is acceptable.

Table 6. AVE and Correlations.

\begin{tabular}{cccccc}
\hline Construct & KS & OI & OL & RG & RE \\
\hline Knowledge sharing & 0.74 & & & & \\
Organizational innovation & 0.49 & 0.84 & & & \\
Organizational learning & 0.63 & 0.46 & 0.79 & & \\
Gender & -0.14 & -0.01 & -0.33 & 1 & 1 \\
Education & 0.12 & 0.13 & 0.18 & 0.01 & \\
\hline
\end{tabular}

This study determines the fitness of the model through various critical indicators, including the goodness-of-fit index model (GFI), the Chi-square minimum/df (CMIN/df), and the root-mean-square error (RMSE) of the approximation. Further, the incremental fit measures, including the adjusted-goodness-of-fit index (AGFI), the normed-fit-index (NFI) value, and the comparative-fit-index (CFI) value, were measured. The parsimonious fit measures including the parsimony-normed-fit-index (PNFI) value and the parsimony-goodness-of-fit-index (PGFI) values were measured. Table 7 represents that all of the fitness indicators met acceptable standards, and the results indicate that the model of this current research has acceptable validity and reliability.

Table 7. Fit index of the confirmatory factor analysis (CFA) model.

\begin{tabular}{ccc}
\hline Fit Index & Score & Recommended Threshold Value \\
\hline Absolute Fit Measures & & \\
CMIN/df & 1.549 & $\leq 2 \mathrm{a} ; \leq 5 \mathrm{~b}$ \\
GFI & 0.894 & $\geq 0.90 \mathrm{a} ; \geq 0.80 \mathrm{~b}$ \\
RMSEA & 0.040 & $\leq 0.80 \mathrm{a} ; \leq 0.10 \mathrm{~b}$ \\
NFI & 0.920 & $\geq 0.90 \mathrm{a}$ \\
\hline
\end{tabular}


Table 7. Cont.

\begin{tabular}{ccc}
\hline Fit Index & Score & Recommended Threshold Value \\
\hline AGFI & 0.869 & $\geq 0.90 \mathrm{a} ; \geq 0.80 \mathrm{~b}$ \\
CFI & 0.974 & $\geq 0.90 \mathrm{a}$ \\
Parsimonious Fit Measures & & Greater is good \\
PGFI & 0.727 & Greater is good \\
PNFI & 0.803 &
\end{tabular}

Note: a: Acceptability: Yes, acceptable; b: Acceptability: Marginal.

\subsection{Evaluation of the Structural Model}

In this proposed study model, we measured and affirmed the validity and reliability values of these selected measurement models. In the next phase, we evaluated the process by describing how to measure/assess the outcomes of an inner structural model. This study review applied a statistical tool, SEM (Structural Equation Modeling) to determine the proposed/formulated hypotheses. Figure 3 and Table 8 present the findings of this study. Figure 3 presents the outcomes of the model.

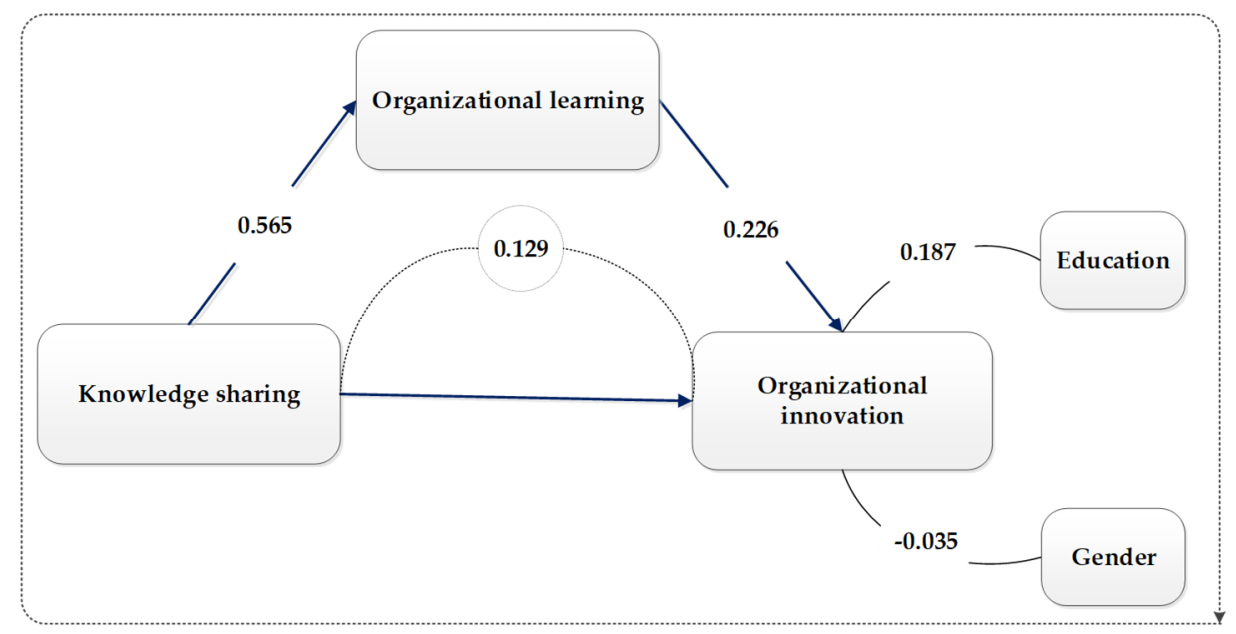

Figure 3. Structural Model Path Coefficients.

Table 8. Structural model results.

\begin{tabular}{cccccc}
\hline Hypothesis & Relationships & Proposed Effect & Estimates & $p$ & Results \\
\hline H1 & KS-OI & + & $0.732^{* * *}$ & $<0.001$ & Supported \\
H2 & KS-OL & + & $0.565^{* * *}$ & $<0.001$ & Supported \\
H3 & OL-OI & + & $0.226^{* * *}$ & $<0.001$ & Supported \\
H4 & KS-OL-OI & + & $0.129^{* * *}$ & $<0.001$ & Supported \\
(C/V) & Gender-OI & + & -0.035 & 0.358 & Not supported \\
(C/V) & Education-OI & + & $0.187^{* * *}$ & $<0.001$ & Supported \\
\hline
\end{tabular}

Note: $+=$ positive effect, $\mathrm{C} / \mathrm{V}=$ Control variables, ${ }^{* * *} p<0.001$

\subsubsection{Analysis of the Study Model Showing a Direct Effect}

The results of the survey presented in Table 9 and Figure 3 describe the immediate impacts of the independent and dependent variables. H1 claims, "A significant positive association exists between knowledge sharing and organizational innovation in Pakistani Islamic banks and the achievement of sustainable performance." The findings confirm the presence of a statistically significant, positive and considerably large impact, and the results confirm all of the proposed hypotheses of the study with an overall satisfaction level. 
$\mathrm{H} 1$ describes the positive relationship between knowledge sharing in Islamic banks and organizational innovation, and the study outcomes (KS $=0.732, p=0.000)$ confirm H1.

In formulating $\mathrm{H} 2$, this review claimed, "Knowledge sharing positively influences organizational learning in Pakistani Islamic banks." Accordingly, H2 describes a positive effect of knowledge sharing on learning in Islamic banks, indicating an organizational learning environment. The findings of Table 9 endorse $\mathrm{H} 2(\mathrm{KS}=0.565, p=0.001)$.

For H3, the study review stated, "Organizational learning positively influences organizational innovation in Pakistani Islamic banks." The study developed H3, and claims that learning in Pakistani Islamic banks (OL) has a positive impact upon organizational innovation. The study outcomes, as shown in Table 9, endorse $\mathrm{H} 3$ and the study findings $(\mathrm{OL}=0.226, p=0.001)$ confirm the validity of $\mathrm{H} 3$.

Concerning the validity of $\mathrm{H} 4$, this model proposed, "Organizational learning in Islamic banks mediates a relationship between knowledge sharing and organizational innovation in Islamic banks." The results presented in Tables 8 and 9 endorse $\mathrm{H} 4$ and confirm its validity. The results (OL $=0.129$, $p=0.001$ ) indicate that organizational learning in Pakistani Islamic banks mediates the relationship between KS, and OI in Islamic banks, as indicated in Tables 8 and 9. The results (Gender $=-0.035$, $p<0.358$ ) also depict that there is no significant linkage between gender and organizational innovation (OI) in Islamic banks.

Table 9. Analysis of total, indirect, and direct effects.

\begin{tabular}{cccc}
\hline Dependent Factor/Predictor & OL & OI & KS \\
\hline Direct effect & & & \\
\hline OI & 0.565 & 0.732 & 0.275 \\
OL & & & 0.129 \\
Total effect-OI & & & 0.683 \\
Indirect effect-OI & & & 0.408 \\
\hline
\end{tabular}

Note: OL represents organizational learning, OI represents organizational innovation, and KS represents knowledge sharing.

\subsubsection{Analysis of Total and Indirect Effects}

This study proposed hypotheses for examining the linkages among selected variables of the proposed study model. The study survey was performed to analyze and assess the direct effects of knowledge sharing on organizational innovation practices in Islamic banks. This research review also inspected the indirect impact of knowledge sharing practices in Pakistani Islamic banks on bank/corporate learning culture.

The results presented in Table 9 represent the findings of this survey, and they endorse the proposed model's hypotheses. The findings of this review show the impacts of knowledge sharing and innovation for attaining sustainable performance in Islamic banks through the mediation of organizational learning. The results of this review reveal that the indirect effect of knowledge sharing on organizational change is more significant than its direct impact, as indicated $(0.408>0.275)$ in Table 9. This study selected gender and education as control variables, and the results show that an appropriate level of education is associated with a significant positive effect on the progress of OI. The findings indicate that a higher level of employee knowledge influences an organization's innovation capacity. The estimated value of education (Edu. $=0.187, p<0.001$ ) endorses the impact of the education level of the employees on OI.

\section{Discussion}

This detailed study review investigates the effects of knowledge sharing on organizational innovation practices in Pakistani Islamic banks through the mediating impact of corporate learning practices. The proposed study model was used to perform a focalized investigation to explore the direct influence of knowledge sharing in Islamic banks on innovation practices in banks and other 
organizations operating in various cities of Pakistan. This research review also examines the indirect effects of knowledge sharing on learning processes in Pakistani Islamic banks. Organizational learning in Islamic banks refers to the procedures which create, retain and transfer knowledge among the employees of an organization. However, organizations improve over time, and they gain experience, establishing a broader body of knowledge, which improves their organization ability, for instance, organizational methods can enhance production efficiency and lead to the development of beneficial relationships with investors. Knowledge comes from four different units, and an organization gains knowledge in four forms of learning through organizational communities such as groups and individuals, and through organizational and inter-organizational methods. The rate of organizational learning is influenced by employees' personal capacity, proficiency, structures and technological improvements in the organizations, routines and methods of coordination [112]. Organizational learning occurs through the processes of organizational communities such as individuals and various groups, departments and divisions, and it changes as a result of organizational experience [113].

The methods of successful and advantageous organizational learning enhance knowledge sharing among employees within the organizations, and empower business firms to initiate critical actions and behaviors to gain the organizational settings in order to identify the real situation. Later, it helps the employees to understand the conditions and respond to circumstances accordingly $[6,54]$.

The existing body of literature on knowledge sharing permits the banking industry to improve organizational learning, allowing it to attain sustainable growth. Earlier studies provide evidence that the idea of knowing consists of understanding, thinking, acquiring, learning and sharing information, which shows a tradeoff connection [30,31]. Yang (2007) reports that knowledge sharing permits organizations to gain individual learning flow, and it integrates the day-to-day consumption of knowledge. In addition, he argues that the employees of an organization typically develop a common understanding by sharing gained knowledge, thoughts, beliefs, experiences and insights, common empathy, and the use of applications, factors which refer to organizational knowledge. Knowledge sharing practices enhance the skills of the employees through the learning process, and they also contribute to the overall performance and growth of an organization [49]. Knowledge sharing and organizational learning are critical for organizations to attain sustainable production, and these are closely associated with each other. Knowledge sharing has evolved to represent indispensable knowledge, and researchers consider it to be a requirement of the innovation process. Therefore, the introduction of practical and effective organizational learning approaches is an efficient and effective source of organizational learning [30,31].

Knowledge management has three major dimensions: Knowledge acquisition, conversion and the applications of knowledge. In business organizations, knowledge sharing is an integral part of the process of knowledge management. The model of knowledge management (KM) presents the following outlines: Knowledge development, knowledge acquisition, knowledge refinement, knowledge sharing, knowledge transfer and the use of the knowledge. All of these activities lead to improvements in organizational performance. Knowledge sharing has two dimensions, which are collecting and donating knowledge, and these are the further sub-dimensions of knowledge management within the organizational learning environment. Typically, knowledge sharing is a critical issue in business firms, and it leads to an organization's success or survival [32]. In a previous study, Aragón Correa et al. (2007) identify that a positive relationship exists between learning and organizational innovation processes in business organizations [55]. In addition, they claim that, theoretically, organizational learning impacts organizational innovation, leading to the achievement of sustainable performance [56]. Considering the various dimensions of organizational learning, past literature provides evidence that organizations practice a higher level of innovation in their processes through the competitive learning processes, thereby achieving sustainable performance [57]. Santos et al. (2009), claim the same findings in their study, showing that organizations introduce innovative products and services to compete in a very competitive business environment [58]. In the literature, scholars argue and identify that organizational learning is a prerequisite of the innovation process, 
and it positively influences the innovation process $[59,60]$. These scholars realize that organizational learning improves the rate of change in products or services, and previous literature reveals that there is a relationship between the increasing rate of learning and the expansion of innovation in firms [60-62].

The developments of learning emphasizes the requirements for continuous evaluation and adaptation, and it refers to the rational debate that an organization's principles reinforce its willingness to adopt innovative strategies, and its inclination to have original thoughts $[63,64]$.

The existing body of literature documents the theory that qualifications, work experience, working relationships and individual income might meaningfully impact knowledge sharing, motivation and willingness [67]. A previous study reveals that organizations with employees who have less job experiences typically exercise greater intentions of knowledge sharing, and scholars identified the same findings $[68,69]$. Bilgihan et al. (2016) identifies the idea that trust among employees encourages knowledge sharing behaviors in organizations. However, belief is also an essential element, which stimulates knowledge sharing by individuals [72]. Likewise, efficiency in the organizational innovation process helps with the introduction of new products or services, and it helps to modernize the obsolete structural and operational processes, which additionally might result in improved products and services, thereby satisfying buyers and other stakeholders. Thus, the existing body of literature helps to categorize it into two phases.

The first stage focuses on the processes and mechanisms of how knowledge sharing contributes to an organization's innovation performance, and the second phase identifies the factors that can mediate this mechanism. Based on the above evidence, this study survey identifies that learning in Islamic banks mediates the association between knowledge sharing and innovation in Islamic banks.

\section{Conclusions}

The existing body of scientific literature provides evidence that knowledge sharing practices in Islamic banks significantly affect innovation processes in firms. Thus, firms' creative capabilities and the organizational practices of the knowledge sharing environment are critical. Knowledge sharing permits employees to share their experiences and knowledge, thereby promoting the innovation process. This study integrates the existing body of literature on knowledge sharing and develops four hypotheses to examine how knowledge sharing influences the innovation processes carried out by employees of Pakistani Islamic banks directly and indirectly. The findings of this defined framework endorse the proposed claims, and the results confirm the validity of all of the assumptions. The results show a substantial positive linkage between knowledge sharing and organizational innovation in Pakistani Islamic banks. The results also endorse the presence of a strong and positive association between organizational innovation and learning in Islamic banks. The survey findings present a positive association between knowledge sharing and learning in Islamic banks, and the outcomes of this study assessment indicate that knowledge sharing among employees helps to boost organizational innovation, both indirectly and directly, by establishing organizational learning systems or developing a learning culture within the employees of the organizations to stimulate the sharing, debating and practicing of the concepts of innovation. Titi Amayah (2013) identifies that knowledge sharing by employees is a critical component for Islamic banks to attain feasible advantages to achieve their business objectives in terms of knowledge economy [114]. Titi Amayah (2013) also reported that knowledge sharing is a challenging task for Islamic banks because of continuous personnel knowledge growth, and the interchangeability of knowledge with organizational memory [114].

The findings of this study survey indicate a direct effect of independent (KS) and dependent OI) variables, as indicated in Table 9. H1 claims that "A significant positive association exists between knowledge sharing and organizational innovation in Pakistani Islamic banks and the attainment of sustainable performance." The results confirm a statistically positive and substantial impact and agree with the proposed hypotheses of this study model. H1 describes a positive relationship between the knowledge sharing in Pakistani Islamic banks and organizational innovation, and the results confirm H1. H2 states that "Knowledge sharing positively influences organizational learning in 
Pakistani Islamic banks." Therefore, H2 describes significant positive impacts of knowledge sharing on learning in Islamic banks, and it forms the organizational learning environment in Islamic banks. The findings shown in Table 9 endorse H2. H3 states that "Organizational learning positively influences organizational innovation in Pakistani Islamic banks." The study claims that learning (OL) in Pakistani Islamic banks has a positive impact on organizational innovation. The study results confirm the validity of $\mathrm{H} 3$, as shown in Table 9. H4 claims that "Organizational learning in Islamic banks mediates a relationship between knowledge sharing and organizational innovation in Islamic banks." The results confirm the validity of $\mathrm{H} 4$, as shown in Tables 8 and 9. The results reveal that organizational learning in Islamic banks mediates the link between knowledge sharing and innovation (KS and OI) in Islamic banks. The study findings also indicate that there is not a strong association between gender and organizational innovation (OI) in Islamic banks. The results show that organizational learning in Islamic banks mediates the relationship between knowledge sharing and innovation in Islamic banks. Thus, knowledge sharing and organizational learning are an integral part of achieving a sustainable performance in business organizations, and knowledge sharing and learning are closely interlinked and associated in Islamic banks. The process of organizational learning leads to knowledge management, which leads to further innovation. Knowledge management positively impacts learning in Islamic banks, and it has a positive impact on innovative behaviors and change in organizations [30,31].

The primary purposes of the model were to scrutinize the influences of knowledge sharing practices on organizational innovation processes and to determine how organizational learning applications help Islamic banks operating in diverse cities in Pakistan. Banks use knowledge sharing to build new capabilities to initiate marketing activity and adopt various strategies to enhance profitability. This study develops a conceptual model/framework by utilizing organizational learning and resource-based-view (RBV) theory, and debates that investment in knowledge sharing and innovation processes might support the development of marketing-related skills [115]. The findings suggest that it is critical for Islamic Banks and other organizations to merge knowledge sharing practices in their marketing strategies to increase customers' engagement and improve their performance [116]. This study model indicates that knowledge sharing among employees has significant effects on organizational innovation through the mediating impact of organizational learning on attaining enhanced performance [117]. The findings of this particular survey provide thought-provoking facts about Pakistani Islamic banks, and the results contribute to the existing body of literature on KS, OI, and OL, as this study explores the association between knowledge sharing and innovation processes in Islamic banks using learning as a mediation variable [118-122]. The findings provide useful managerial insight into the productivity of knowledge sharing applications within organizations. This specific framework contributes to scientific knowledge by bridging gaps in the literature. This study significantly contributes, both theoretically and practically, to information on knowledge sharing and organizational learning, and their effects on organizational innovation in Islamic Banks operating in Pakistan [123-126]. This study offers a conceptual background, defines the research procedure and available data set from the selected respondents, conducts analyses and provides results, links the findings with theory and practices, and clarifies potential future research areas.

\section{Recommendations and Implications}

The Islamic banks operating in Pakistan should consider promoting a culture of practicing knowledge sharing among their employees by introducing the direct integration of knowledge sharing through organizational strategies, or by motivating and training employees. This might change their behaviors and attitudes towards the adoption of knowledge sharing for the promotion of innovation processes. Islamic banks need to emphasize the procedures of knowledge sharing and organizational learning among existing employees, since the efficiency of the knowledge sharing process depends upon the behavior and attitudes of the employees at large. The comprehensive analysis conducted in this study about employees'/workers' attitudes suggests that the promotion of knowledge sharing permits Pakistani Islamic banks to develop an ideal, promising and appropriate environment for 
practicing knowledge sharing. Accordingly, Pakistani Islamic bank management needs to emphasize the launching of policies to educate and train employees through educational development and training programs. This is a critical and valuable source of promoting knowledge sharing and creativity in Pakistani Islamic banks. This study also has some limitations. The research survey had a cross-sectional design; therefore, it offers the cause and effect relations between the selected variables, which might seem to vary in the long term. Researchers might consider carrying out longitudinal studies in the future to avoid these limitations and thus provide improved results. These findings cover the service-providing organizations and Islamic Banks in the context of the Pakistani Islamic banking sector. Future studies might focus on covering different research settings to present an overall view of the predicting variables. The findings of this specific study offer insightful evidence through empirical research, which describe the positive and substantial effects of knowledge sharing and organizational learning on the development and promotion of corporate innovation to ensure the long-term sustainable growth of Pakistani Islamic banks. The findings indicate that knowledge-sharing practices are critical, as knowledge is the most valuable resource of an organization for developing advantageous relations among co-workers, and motivating employees enhance their knowledge sharing attitudes and behavior to promote a learning culture and sustainable growth. Knowledge sharing practices and creativity permit business managers, supervisors and other officers to build an innovative culture, which encourages the development of organizational innovation process in Islamic banks operating in Pakistan, leading to sustainable professional progress.

Author Contributions: J.A. (Abbas) completed introduction, literature, methodology, discussion, conclusion and edited the original manuscript, I.H. (Iftikhar) conceptualized the idea, supervised this project, and designed method section, S.H. (Safdar) contributed in literature and data process, S.A. (Sabhat), I.S. (Imrab) data collection. Data collection. B.N. (Niu) provided resources and reviewed the edited manuscript.

Funding: This work is partially supported by The National Natural Science Foundation of China (Grants Nos. 71571120), Research Cultivation Project from Shenzhen Institute of Information Technology (ZY201717) and Innovating and Upgrading Institute Project from Department of Education of Guangdong Province(2017GWTSCX038). The authors also acknowledge the support from the College of Management, Shenzhen University, Nanshan District, Shenzhen; Guangdong, China.

Acknowledgments: Special thanks to MDPI professional language editing services to ensure that English grammar is free of mistakes for this manuscript. L., Jinzhu supervised this project.

Conflicts of Interest: The authors are well informed about the study's objectives, provided consent, and have declared that they have no competing interest.

\section{Appendix A}

Table A1. Please Tick $(\checkmark)$ in each, which best describes the level of knowledge sharing in your bank. 1 = VR: Very Rarely, 2 = R: Rarely, 3 = M: Moderately, 4 = F: Frequently, 5 = VF: Very Frequently.

\begin{tabular}{|c|c|c|c|c|c|c|}
\hline Items & Knowledge Sharing [76-79,89-96] & VR & $\mathbf{R}$ & $\mathbf{M}$ & $\mathbf{F}$ & VF \\
\hline KS-1 & I expect to receive monetary rewards in return for my knowledge sharing. & & & & & \\
\hline KS-2 & $\begin{array}{l}\text { I expect to receive additional points for promotion in return for knowledge } \\
\text { sharing. }\end{array}$ & & & & & \\
\hline KS-3 & $\begin{array}{l}\text { I expect to receive an honor such as educational opportunity in return for my } \\
\text { knowledge sharing. }\end{array}$ & & & & & \\
\hline KS-4 & $\begin{array}{l}\text { My knowledge sharing would strengthen the tie between me and existing } \\
\text { members in the bank. }\end{array}$ & & & & & \\
\hline KS-5 & $\begin{array}{l}\text { My knowledge sharing would get me well acquainted with new members in } \\
\text { the bank. }\end{array}$ & & & & & \\
\hline KS-6 & $\begin{array}{l}\text { My knowledge sharing would expand the scope of my associations with } \\
\text { other members in the bank. }\end{array}$ & & & & & \\
\hline KS-7 & $\begin{array}{l}\text { My knowledge sharing would draw smooth cooperation from members } \\
\text { in future. }\end{array}$ & & & & & \\
\hline KS-9 & My knowledge sharing would help other members in bank to solve problems. & & & & & \\
\hline KS-8 & $\begin{array}{l}\text { My knowledge sharing would make strong relationships with members who } \\
\text { have common interests in the bank. }\end{array}$ & & & & & \\
\hline
\end{tabular}


Table A1. Cont.

\begin{tabular}{|c|c|c|c|c|c|c|}
\hline Items & Knowledge Sharing [76-79,89-96] & VR & $\mathbf{R}$ & $\mathbf{M}$ & $\mathbf{F}$ & VF \\
\hline KS-10 & My knowledge sharing would create new business opportunities for bank. & & & & & \\
\hline KS-11 & My knowledge sharing would improve work processes in the bank. & & & & & \\
\hline KS-12 & My knowledge sharing would increase the productivity in the bank. & & & & & \\
\hline KS-13 & $\begin{array}{l}\text { My knowledge sharing would help the bank to achieve its performance } \\
\text { objectives. }\end{array}$ & & & & & \\
\hline KS-14 & My knowledge sharing with other bank members is good. & & & & & \\
\hline KS-15 & My knowledge sharing with other bank members is pleasant. & & & & & \\
\hline KS-16 & My knowledge sharing with other bank members is valuable. & & & & & \\
\hline KS-17 & My knowledge sharing with other bank members is wise. & & & & & \\
\hline KS-18 & I will share my knowledge with more bank members. & & & & & \\
\hline KS-19 & I will always provide my knowledge at request of other bank members. & & & & & \\
\hline KS-20 & $\begin{array}{l}\text { I intend to share my knowledge with other bank members frequently } \\
\text { in future }\end{array}$ & & & & & \\
\hline KS-21 & $\begin{array}{l}\text { I try to share my knowledge with other organizational members in an } \\
\text { effective way }\end{array}$ & & & & & \\
\hline KS-22 & $\begin{array}{l}\text { I will open my knowledge to anyone in the organization if it is helpful to } \\
\text { the bank. }\end{array}$ & & & & & \\
\hline
\end{tabular}

Table A2. Please Tick $(\checkmark)$ in each item the number that best describe Organizational Innovation for your bank. 1 = MWC: Much weaker than the competitor, $2=$ WC: Weaker than the competitor, $3=\mathrm{EC}$ : Equal to competitor, $4=$ SC: Stronger than the competitor, $5=$ MSC: Much stronger than the competitor.

\begin{tabular}{|c|c|c|c|c|c|c|}
\hline Items & Organizational Innovation $[97,100-102]$ & MWC & WC & EC & SC & MSC \\
\hline OI-1 & $\begin{array}{l}\text { Efforts to develop new products/services in terms of hours/person, teams } \\
\text { and training involved. }\end{array}$ & & & & & \\
\hline OI-2 & Pioneer disposition to introduce new products/services. & & & & & \\
\hline OI-3 & Number of new products/services introduced. & & & & & \\
\hline OI-4 & $\begin{array}{l}\text { Efforts to develop new products/services in terms of hours/person, teams } \\
\text { and training involved. }\end{array}$ & & & & & \\
\hline OI-5 & Pioneer disposition to introduce new products/services. & & & & & \\
\hline OI-6 & Number of new products/services introduced. & & & & & \\
\hline OI-7 & Novelty of administrative systems. & & & & & \\
\hline OI-8 & Search for new administrative systems by managers. & & & & & \\
\hline OI-9 & Pioneer disposition to introduce new administrative systems & & & & & \\
\hline
\end{tabular}

Table A3. Please Tick $(\checkmark)$ in each item the number that best describe Organizational Learning for your bank. 1 = SD: Strongly Disagree, $2=$ D: Disagree, $3=$ N: Neutral, $4=$ A: Agree, $5=$ SA: Strongly Agree.

\begin{tabular}{|c|c|c|c|c|c|c|}
\hline Items & Organizational Learning $[103-106,108]$ & SD & D & $\mathbf{N}$ & A & SA \\
\hline OL-1 & The personnel often participate in shows and events. & & & & & \\
\hline OL-2 & $\begin{array}{l}\text { Our bank has a resourceful \& consolidated research and development } \\
\text { policy. }\end{array}$ & & & & & \\
\hline OL-3 & Our bank test creative thoughts and tactics on workplace regularly. & & & & & \\
\hline OL-4 & $\begin{array}{l}\text { Our bank takes proper mechanisms to ensure the distribution of the best } \\
\text { practices between the diverse fields of the activity. }\end{array}$ & & & & & \\
\hline OL-5 & $\begin{array}{l}\text { Some people in the bank participate in different divisions or teams, and } \\
\text { they perform as connections among them. }\end{array}$ & & & & & \\
\hline OL-6 & $\begin{array}{l}\text { All employees of our bank convey the similar goal to which they sense } \\
\text { dedicated. }\end{array}$ & & & & & \\
\hline OL-7 & $\begin{array}{l}\text { Workers exchange experiences and knowledge through mutual } \\
\text { conversion. }\end{array}$ & & & & & \\
\hline OL-8 & Our bank usually practices and encourage teamwork. & & & & & \\
\hline OL-9 & $\begin{array}{l}\text { Our bank has a complete record of employees/experts with respect to } \\
\text { their area of specialization. If anyone needs, he/she can find at any time. }\end{array}$ & & & & & \\
\hline OL-10 & Our bank has a complete database of its customers. & & & & & \\
\hline OL-11 & All the employees are having access to bank's databases and records. & & & & & \\
\hline
\end{tabular}




\section{References}

1. Tavakoli, I.; Lawton, J. Strategic thinking and knowledge management. In Handbook of Business Strategy; Emerald Group Publishing Limited: Bingley, UK, 2005; Volume 6, pp. 155-160.

2. Johannessen, J.A. Knowledge Management as a Strategic Asset: An Integrated, Historical Approach; Emerald Publishing Limited: Bingley, UK, 2018.

3. Mizintseva, M.F.; Gerbina, T.V. Knowledge Management: A Tool for Implementing the Digital Economy. In Scientific and Technical Information Processing; Pleiades Publishing: New York, NY, USA, 2018; Volume 45, pp. $40-48$.

4. Ali, H.M.; Ahmad, N.H. Nor Hayati Knowledge management in Malaysian bank: A new paradigm. J. Knowl. Manag. Pract. 2006, 7, 1-13.

5. Cegarra-Navarro, J.-G.; Jiménez-Jiménez, D.; Fernández-Gil, J.-R. Improving customer capital through relationship memory at a commercial bank in Spain. Knowl. Manag. Res. Pract. 2014, 12, 310-321. [CrossRef]

6. Barachini, F. Cultural and social issues for knowledge sharing. J. Knowl. Manag. 2009, 13, 98-110. [CrossRef]

7. Singh, S.K.; Gupta, S.; Busso, D.; Kamboj, S. Top management knowledge value, knowledge sharing practices, open innovation and organizational performance. J. Bus. Res. 2019, 39, 8899-8908. [CrossRef]

8. Tongurai, J.; Vithessonthi, C. The impact of the banking sector on economic structure and growth. Int. Rev. Financ. Anal. 2018, 56, 193-207. [CrossRef]

9. Olsen, M.D.; Connolly, D.J. Experience-based travel: How technology is changing the hospitality industry. Cornell Hotel Restaur. Adm. Q. 2000, 41, 30-40. [CrossRef]

10. Akhtar, C.S.; Awan, S.H.; Naveed, S.; Ismail, K. A comparative study of the application of systems thinking in achieving organizational effectiveness in Malaysian and Pakistani banks. Int. Bus. Rev. 2018, 27, 767-776. [CrossRef]

11. Hassan, M.K.; Aliyu, S. A contemporary survey of islamic banking literature. J. Financ. Stab. 2018, 34, 12-43. [CrossRef]

12. Salman, A.; Nawaz, H. Islamic financial system and conventional banking: A comparison. Arab Econ. Bus. J. 2018, 13, 155-167. [CrossRef]

13. Narayan, P.K.; Phan, D.H.B. A survey of Islamic banking and finance literature: Issues, challenges and future directions. Pac. Basin Financ. J. 2019, 53, 484-496. [CrossRef]

14. Kontot, K.; Hamali, J.; Abdullah, F. Determining Factors of Customers' Preferences: A Case of Deposit Products in Islamic Banking. Procedia Soc. Behav. Sci. 2016, 224, 167-175. [CrossRef]

15. Riaz, U.; Burton, B.; Monk, L. Perceptions on the accessibility of Islamic banking in the UK-Challenges, opportunities and divergence in opinion. Account. Forum 2017, 41, 353-374. [CrossRef]

16. Kishore Jain, K.; Sandhu, M.S.; Wai Ling, C. Knowledge sharing in an American multinational company based in Malaysia. J. Workplace Learn. 2009, 21, 125-142.

17. Fields, Z. Collective Creativity for Responsible and Sustainable Business Practice; IGI Global: Dauphin, PA, USA, 2016.

18. Ciulli, F.; Kolk, A. Incumbents and business model innovation for the sharing economy: Implications for sustainability. J. Clean. Prod. 2019, 214, 995-1010. [CrossRef]

19. Estrada, I.; Faems, D.; De Faria, P. Coopetition and product innovation performance: The role of internal knowledge sharing mechanisms and formal knowledge protection mechanisms. Ind. Mark. Manag. 2016, 53, 56-65. [CrossRef]

20. Antunes, H.d.J.G.; Pinheiro, P.G. Linking knowledge management, organizational learning and memory. Available online: https://www.sciencedirect.com/science/article/pii/S2444569X19300319 (accessed on 1 January 2019).

21. Huang, J.C.; Newell, S. Knowledge integration processes and dynamics within the context of cross-functional projects. Int. J. Proj. Manag. 2003, 21, 167-176. [CrossRef]

22. Laudon, K.C.; Laudon, J.P. Management Information Systems: Managing the Digital Firm, Student Value Edition Plus Mymislab with Pearson Etext_Access Card Package; Prentice Hall: Upper Saddle River, NJ, USA, 2015.

23. Kremer, H.; Villamor, I.; Aguinis, H. Innovation leadership: Best-practice recommendations for promoting employee creativity, voice, and knowledge sharing. Bus. Horiz. 2019, 62, 65-74. [CrossRef]

24. Iqbal, Z.; Mirakhor, A. Ethical Dimensions of Islamic Finance: Theory and Practice; Springer International Publishing: Basel, Switzerland, 2017. 
25. Khan, F. Islamic Banking in Pakistan: Shariah-Compliant Finance and the Quest to Make Pakistan More Islamic; Taylor \& Francis Group: Didcot, UK, 2019.

26. Moore, C.H.; Henry, C.M.; Wilson, R. The Politics of Islamic Finance; Edinburgh University Press: Edinburgh, UK, 2004.

27. McNaughton, R.; Darroch, J. Beyond market orientation: Knowledge management and the innovativeness of New Zealand firms. Eur. J. Mark. 2003, 37, 572-593.

28. Mardani, A.; Nikoosokhan, S.; Moradi, M.; Doustar, M. The Relationship Between Knowledge Management and Innovation Performance. J. High Technol. Manag. Res. 2018, 29, 12-26. [CrossRef]

29. López-Nicolás, C.; Meroño-Cerdán, Á.L. Strategic knowledge management, innovation and performance. Int. J. Inf. Manag. 2011, 31, 502-509. [CrossRef]

30. Hsiao, H.-C.; Chang, J.-C. The role of organizational learning in transformational leadership and organizational innovation. Asia Pac. Educ. Rev. 2011, 12, 621. [CrossRef]

31. Management Association, I.R. Organizational Culture and Behavior: Concepts, Methodologies, Tools, and Applications: Concepts, Methodologies, Tools, and Applications; IGI Global: Dauphin, PA, USA, 2017.

32. Evans, M.; Dalkir, K.; Bidian, C. A holistic view of the knowledge life cycle: The knowledge management cycle (KMC) model. Electron. J. Knowl. Manag. 2012, 12, 47.

33. Seleim Ahmed, A.S. Understanding the knowledge management-intellectual capital relationship: A two-way analysis. J. Intellect. Cap. 2011, 12, 586-614. [CrossRef]

34. Mitić, S.; Nikolić, M.; Jankov, J.; Vukonjanski, J.; Terek, E. The impact of information technologies on communication satisfaction and organizational learning in companies in Serbia. Comput. Hum. Behav. 2017, 76, 87-101. [CrossRef]

35. O'Neill, B.S.; Adya, M. Knowledge sharing and the psychological contract. J. Manag. Psychol. 2007, 22, 411-436. [CrossRef]

36. Foss, N.J.; Husted, K.; Michailova, S. Governing Knowledge Sharing in Organizations: Levels of Analysis, Governance Mechanisms, and Research Directions. J. Manag. Stud. 2010, 47, 455-482. [CrossRef]

37. Mengmeng, Z.; Yamin, Z.; Zhiwei, Z.; Xiaomin, G. Research on Intensive Facts about Explicit Case of Tacit Knowledge. Procedia Eng. 2017, 174, 317-323. [CrossRef]

38. Nonaka, I.; Takeuchi, H. The Knowledge-creating Company: How Japanese Companies Create the Dynamics of Innovation; Oxford University Press: Oxford, UK, 1995.

39. Alsharo, M.; Gregg, D.; Ramirez, R. Virtual team effectiveness: The role of knowledge sharing and trust. Inf. Manag. 2017, 54, 479-490. [CrossRef]

40. Spender, J.C. Organizational knowledge, learning and memory: Three concepts in search of a theory. J. Organ. Chang. Manag. 1996, 9, 63-79. [CrossRef]

41. Spender, J.C. Making knowledge the basis of a dynamic theory of the firm. Strateg. Manag. J. 1996, 17, 45-62. [CrossRef]

42. Adloff, F.; Gerund, K.; Kaldewey, D. Revealing Tacit Knowledge: Embodiment and Explication; Transcript Verlag: Bielefeld, Germany, 2015.

43. Nguyen, H.L.; Jung, J.E. SocioScope: A framework for understanding Internet of Social Knowledge. Future Gener. Comput. Syst. 2018, 83, 358-365. [CrossRef]

44. Chilton, M.A. Knowledge Management and Competitive Advantage: Issues and Potential Solutions: Issues and Potential Solutions; IGI Global: Dauphin, PA, USA, 2013.

45. Khan, M.T.; Azam, N.; Khalid, S.; Yao, J. A three-way approach for learning rules in automatic knowledge-based topic models. Int. J. Approx. Reason. 2017, 82, 210-226. [CrossRef]

46. Turner, S.; Higginson, J.; Oborne, C.A.; Thomas, R.E.; Ramsay, A.I.; Fulop, N.J. Codifying knowledge to improve patient safety: A qualitative study of practice-based interventions. Soc. Sci. Med. 2014, 113, 169-176. [CrossRef] [PubMed]

47. Machacek, E.; Hess, M. Whither 'high-tech' labor? Codification and (de-)skilling in automotive components value chains. Geoforum 2017, 99, 287-295. [CrossRef]

48. Cabitza, F.; Ciucci, D.; Locoro, A. Exploiting collective knowledge with three-way decision theory: Cases from the questionnaire-based research. Int. J. Approx. Reason. 2017, 83, 356-370. [CrossRef]

49. Yang, J.T. The impact of knowledge sharing on organizational learning and effectiveness. J. Knowl. Manag. 2007, 11, 83-90. [CrossRef] 
50. Dibella, A.J.; Nevis, E.C.; Gould, J.M. Understanding Organizational Learning Capability. J. Manag. Stud. 1996, 33, 361-379. [CrossRef]

51. Swan, J.; Scarbrough, H.; Robertson, M. The Construction of 'Communities of Practice' in the Management of Innovation. Manag. Learn. 2002, 33, 477-496. [CrossRef]

52. Liedtka, J. Linking Competitive Advantage with Communities of Practice. J. Manag. Inq. 1999, 8, 5-16. [CrossRef]

53. Jamil, G.L. Handbook of Research on Information Architecture and Management in Modern Organizations; IGI Global: Dauphin, PA, USA, 2015.

54. Jones, N.B.; Moesel, D.D.; Herschel, R.T. Using “knowledge champions” to facilitate knowledge management. J. Knowl. Manag. 2003, 7, 49-63. [CrossRef]

55. Aragón-Correa, J.A.; García-Morales, V.J.; Cordón-Pozo, E. Leadership and organizational learning's role on innovation and performance: Lessons from Spain. Ind. Mark. Manag. 2007, 36, 349-359. [CrossRef]

56. García-Morales, V.J.; Jiménez-Barrionuevo, M.M.; Gutiérrez-Gutiérrez, L. Transformational leadership influence on organizational performance through organizational learning and innovation. J. Bus. Res. 2012, 65, 1040-1050. [CrossRef]

57. Liu, C.-H. Creating competitive advantage: Linking perspectives of organization learning, innovation behavior and intellectual capital. Int. J. Hosp. Manag. 2017, 66, 13-23. [CrossRef]

58. Santos-Vijande, M.L.; Sanzo-Perez, M.J.; Alvarez-Gonzalez, L.I.; Vazquez-Casielles, R. Organizational learning and market orientation: Interface and effects on performance. Ind. Mark. Manag. 2005, 34, 187-202. [CrossRef]

59. Hurley, R.F.; Hult, G.T.M. Innovation, Market Orientation, and Organizational Learning: An Integration and Empirical Examination. J. Mark. 1998, 62, 42-54. [CrossRef]

60. Hult, G.T.M.; Hurley, R.F.; Knight, G.A. Innovativeness: Its antecedents and impact on business performance. Ind. Mark. Manag. 2004, 33, 429-438. [CrossRef]

61. İpek, İ. Organizational learning in exporting: A bibliometric analysis and critical review of the empirical research. Int. Bus. Rev. 2019, 28, 544-559. [CrossRef]

62. Xie, X.; Wang, L.; Zeng, S. Inter-organizational knowledge acquisition and firms' radical innovation: A moderated mediation analysis. J. Bus. Res. 2018, 90, 295-306. [CrossRef]

63. Vijande, M.L.S.; Sánchez, J.Á.L. The Effects of Organizational Learning on Innovation and Performance in Kibs: An Empirical Examination. in The Customer is NOT Always Right? In Marketing Orientationsin a Dynamic Business World; Springer International Publishing: Berlin, Germany, 2017.

64. Sheng, M.L.; Chien, I. Rethinking organizational learning orientation on radical and incremental innovation in high-tech firms. J. Bus. Res. 2016, 69, 2302-2308. [CrossRef]

65. Scott, N.; Van Niekerk, M.; de Martino, M. Knowledge Transfer To and Within Tourism: Academic, Industry and Government Bridges; Emerald Publishing Limited: Bingley, UK, 2017.

66. Lee, S.; Kim, S.-H. Role of restaurant employees' intrinsic motivations on knowledge management: An application of need theory. Int. J. Contemp. Hosp. Manag. 2017, 29, 2751-2766. [CrossRef]

67. Hawkins, D.E. Transferring Tourism Knowledge. J. Qual. Assur. Hosp. Tour. 2006, 7, 13-27. [CrossRef]

68. Gaol, F.L.; Hutagalung, F. The Role of Service in the Tourism \& Hospitality Industry. In Proceedings of the Annual International Conference on Management and Technology in Knowledge, Service, Tourism \& Hospitality 2014 (SERVE 2014), Gran Melia, Jakarta, Indonesia, 23-24 August 2014; CRC Press: Boca Raton, FL, USA, 2015.

69. Liu, Q. The Study of Knowledge Sharing Willingness of Employees of International Tourism Hotel Industry in Taichung. Unpublished. Master Thesis, Chaoyang University of Technology, Taichung, Taiwan, 2002.

70. Holste, J.S. Trust and tacit knowledge sharing and use. J. Knowl. Manag. 2010, 14, 128-140. [CrossRef]

71. Lucas Leyland, M. The role of teams, culture, and capacity in the transfer of organizational practices. Learn. Organ. 2010, 17, 419-436. [CrossRef]

72. Bilgihan, A.; Barreda, A.; Okumus, F.; Nusair, K. Consumer perception of knowledge-sharing in travel-related Online Social Networks. Tour. Manag. 2016, 52, 287-296. [CrossRef]

73. Wang, W.-T.; Hou, Y.-P. Motivations of employees' knowledge sharing behaviors: A self-determination perspective. Inf. Organ. 2015, 25, 1-26. [CrossRef]

74. Phillips, P.P.; Stawarski, C.A. Data Collection: Planning for and Collecting All Types of Data; Wiley: Toronto, ON, Canada, 2016. 
75. Bock, G.-W.; Kim, Y.-G. Breaking the Myths of Rewards: An Exploratory Study of Attitudes about Knowledge Sharing. Inf. Resour. Manag. J. 2002, 15, 14-21. [CrossRef]

76. Jauch, L.R. Tailoring Incentives for Researchers. Res. Manag. 2016, 19, 23-27.

77. Gomez-Mejia, L.R.; Balkin, D.B.; Milkovich, G.T. Rethinking rewards for technical employees. Organ. Dyn. 1990, 18, 62-75. [CrossRef]

78. Koning, J.W. Three Other R's: Recognition, Reward and Resentment. Res. Technol. Manag. 1993, 36, 19-29. [CrossRef]

79. Malhotra, Y.; Galletta, D.F. Extending the technology acceptance model to account for social influence: Theoretical bases and empirical validation. In Proceedings of the 32nd Annual Hawaii International Conference on Systems Sciences 1999, HICSS-32, Abstracts and CD-ROM of Full Papers, Maui, HI, USA, 5-8 January 1999.

80. Deluga, R.J. Leader-member exchange quality and effectiveness ratings: The role of subordinate-supervisor conscientiousness similarity. Group Organ. Manag. 1998, 23, 189-216. [CrossRef]

81. Sparrowe, R.T.; Liden, R.C. Process and Structure in Leader-Member Exchange. Acad. Manag. Rev. 1997, 22, 522-552. [CrossRef]

82. Seers, A.; Petty, M.M.; Cashman, J.F. Team-Member Exchange Under Team and Traditional Management. Group Organ. Manag. 2016, 20, 18-38. [CrossRef]

83. Major, D.A.; Kozlowski, S.W.; Chao, G.T.; Gardner, P.D. A longitudinal investigation of newcomer expectations, early socialization outcomes, and the moderating effects of role development factors. J. Appl. Psychol. 1995, 80, 418-431. [CrossRef]

84. Parkhe, A. Strategic Alliance Structuring: A Game Theoretic and Transaction Cost Examination of Interfirm Cooperation. Acad. Manag. J. 1993, 36, 794-829.

85. Stajkovic, A.D.; Luthans, F. Social cognitive theory and self-efficacy: Goin beyond traditional motivational and behavioral approaches. Organ. Dyn. 1998, 26, 62-74. [CrossRef]

86. Gardner, D.G.; Pierce, J.L. Self-Esteem and Self-Efficacy within the Organizational Context. Group Organ. Manag. 2016, 23, 48-70. [CrossRef]

87. Schaubroeck, J.; Merritt, D.E. Divergent Effects Of Job Control On Coping With Work Stressors: The Key Role Of Self-Efficacy. Acad. Manag. J. 1997, 40, 738-754.

88. Gecas, V.; Schwalbe, M.L. Parental Behavior and Adolescent Self-Esteem. J. Marriage Fam. 1986, 48, 37-46. [CrossRef]

89. Fishbein, M.; Ajzen, I. On construct validity: A critique of Miniard and Cohen's paper. J. Exp. Soc. Psychol. 1981, 17, 340-350. [CrossRef]

90. Fishbein, M.; Ajzen, I. Belief, Attitude, Intention, and Behavior: An Introduction to Theory and Research; Addison-Wesley: Boston, MA, USA, 1977.

91. Robinson, J.P.; Shaver, P.R. Measures of Social Psychological Attitudes; Elsevier: Amsterdam, The Netherlands, 1973.

92. Price, J.L. Handbook of Organizational Measurement. Int. J. Manpow. 1997, 18, 305-558. [CrossRef]

93. Fisher, R.J.; Maltz, E.; Jaworski, B.J. Enhancing Communication between Marketing and Engineering: The Moderating Role of Relative Functional Identification. J. Mark. 2018, 61, 54-70. [CrossRef]

94. Darroch, J.; McNaughton, R. Beyond market orientation. Eur. J. Mark. 2003, 37, 572-593. [CrossRef]

95. Manis, J.G.; Meltzer, B.N. A Reader in Social Psychology; Allyn and Bacon: Boston, MA, USA, 1978.

96. Heide, J.B.; Miner, A.S. The Shadow of the Future: Effects of Anticipated Interaction and Frequency of Contact on Buyer-Seller Cooperation. Acad. Manag. J. 1992, 35, 265-291. [CrossRef]

97. Manu, F.A. Innovation Orientation, Environment and Performance: A Comparison of U.S. and European Markets. J. Int. Bus. Stud. 1992, 23, 333-359. [CrossRef]

98. Jiménez-Jiménez, D.; Sanz-Valle, R. Innovation, organizational learning, and performance. J. Bus. Res. 2011, 64, 408-417. [CrossRef]

99. Atuahene-Gima, K. Resolving the Capability-Rigidity Paradox in New Product Innovation. J. Mark. 2018, 69, 61-83. [CrossRef]

100. Oldham, G.R.; Cummings, A. Employee Creativity: Personal and Contextual Factors at Work. Acad. Manag. J. 1996, 39, 607-634.

101. Woodman, R.W.; Sawyer, J.E.; Griffin, R.W. Toward a Theory of Organizational Creativity. Acad. Manag. Rev. 1993, 18, 293-321. [CrossRef] 
102. Hitt, M.A.; Hoskisson, R.E.; Kim, H. International Diversification: Effects on Innovation and Firm Performance in Product-Diversified Firms. Acad. Manag. J. 1997, 40, 767-798.

103. Lei, D.; Slocum, J.W.; Pitts, R.A. Designing organizations for competitive advantage: The power of unlearning and learning. Organ. Dyn. 1999, 27, 24-38. [CrossRef]

104. Slater, S.F.; Narver, J.C. Product-market Strategy and Performance: An Analysis of the Miles and Snow Strategy Types. Eur. J. Mark. 1993, 27, 33-51. [CrossRef]

105. Baker, W.E.; Sinkula, J.M. The Synergistic Effect of Market Orientation and Learning Orientation on Organizational Performance. J. Acad. Mark. Sci. 1999, 27, 411-427. [CrossRef]

106. Jerez-Gómez, P.; Céspedes-Lorente, J.; Valle-Cabrera, R. Organizational learning capability: A proposal of measurement. J. Bus. Res. 2005, 58,715-725. [CrossRef]

107. Tippins, M.J.; Sohi, R.S. IT competency and firm performance: Is organizational learning a missing link? Strateg. Manag. J. 2003, 24, 745-761. [CrossRef]

108. Pérez López, S.; Manuel Montes Peón, J.; José Vázquez Ordás, C. Managing knowledge: The link between culture and organizational learning. J. Knowl. Manag. 2004, 8, 93-104. [CrossRef]

109. Nunnally, J.C. Psychometric Theory 3E; Tata McGraw-Hill Education: New York, NY, USA, 1994.

110. Hair, J.F., Jr.; Hult, G.T.M.; Ringle, C.; Sarstedt, M. A Primer on Partial Least Squares Structural Equation Modeling (PLS-SEM); SAGE Publications: London, UK, 2016.

111. Fornell, C.; Larcker, D.F. Evaluating Structural Equation Models with Unobservable Variables and Measurement Error. J. Mark. Res. 2018, 18, 39-50. [CrossRef]

112. Argote, L. Organizational Learning: Creating, Retaining and Transferring Knowledge; Springer: Berlin, Germany, 2014.

113. Dixon, N.M. The Organizational Learning Cycle: How We Can Learn Collectively; Taylor \& Francis: Didcot, UK, 2017.

114. Titi Amayah, A. Determinants of knowledge sharing in a public sector organization. J. Knowl. Manag. 2013, 17, 454-471. [CrossRef]

115. Abbas, J.; Raza, S.; Nurunnabi, M.; Minai, M.S.; Bano, S. The Impact of Entrepreneurial Business Networks on Firms' Performance Through a Mediating Role of Dynamic Capabilities. Sustainability 2019, 11, 3006. [CrossRef]

116. Abbas, J.; Mahmood, S.; Ali, H.; Raza, M.A.; Ali, G.; Aman, J.; Nurunnabi, M. The Effects of Corporate Social Responsibility Practices and Environmental Factors through a Moderating Role of Social Media Marketing on Sustainable Performance of Business Firms. Sustainability 2019, 11, 3434. [CrossRef]

117. Luo, X.; Zhang, J.; Duan, W. Social media and firm equity value. Inf. Syst. Res. 2013, 24, 146-163. [CrossRef]

118. Abbas, J.; Aqeel, M.; Abbas, J.; Shaher, B.; Jaffar, A.; Sundas, J.; Zhang, W. The moderating role of social support for marital adjustment, depression, anxiety, and stress: Evidence from Pakistani working and nonworking women. J. Affect. Disord. 2019, 244, 231-238. [CrossRef]

119. Abbas, J.; Aman, J.; Nurunnabi, M.; Bano, S. The Impact of Social Media on Learning Behavior for Sustainable Education: Evidence of Students from Selected Universities in Pakistan. Sustainability 2019, 11, 1683. [CrossRef]

120. Azhar, A.; Abbas, J.; Wenhong, Z.; Akhtar, T.; Aqeel, M. Linking infidelity stress, anxiety and depression: Evidence from Pakistan married couples and divorced individuals. Int. J. Hum. Rights Healthc. 2018, 11, 214-228. [CrossRef]

121. Abbas, J.; Aqeel, M.; Wenhong, Z.; Aman, J.; Zahra, F. The moderating role of gender inequality and age among emotional intelligence, homesickness and development of mood swings in university students. Int. J. Hum. Rights Healthc. 2018, 11, 356-367. [CrossRef]

122. Anjum, M.N.; Xiuchun, B.; Abbas, J.; Shuguang, Z. Analyzing predictors of customer satisfaction and assessment of retail banking problems in Pakistan. Cogent Bus. Manag. 2017, 4, 1338842. [CrossRef]

123. Hussain, S.T.; Abbas, J.; Lei, S.; Jamal Haider, M.; Akram, T. Transactional leadership and organizational creativity: Examining the mediating role of knowledge sharing behavior. Available online: https://www. tandfonline.com/doi/full/10.1080/23311975.2017.1361663 (accessed on 1 January 2019).

124. Aman, J.; Abbas, J.; Nurunnabi, M.; Bano, S. The Relationship of Religiosity and Marital Satisfaction: The Role of Religious Commitment and Practices on Marital Satisfaction Among Pakistani Respondents. Behav. Sci. 2019, 9, 30. [CrossRef] [PubMed] 
125. Hussain, T.; Abbas, J.; Wei, Z.; Nurunnabi, M. The Effect of Sustainable Urban Planning and Slum Disamenity on The Value of Neighboring Residential Property: Application of The Hedonic Pricing Model in Rent Price Appraisal. Sustainability 2019, 11. [CrossRef]

126. Aman, J.; Abbas, J.; Mahmood, S.; Nurunnabi, M.; Bano, S. The Influence of Islamic Religiosity on the Perceived Socio-Cultural Impact of Sustainable Tourism Development in Pakistan: A Structural Equation Modeling Approach. Sustainability 2019, 11. [CrossRef]

(C) 2019 by the authors. Licensee MDPI, Basel, Switzerland. This article is an open access article distributed under the terms and conditions of the Creative Commons Attribution (CC BY) license (http://creativecommons.org/licenses/by/4.0/). 